\title{
$A L-A F^{\prime} \bar{A} L A L-I N J \bar{A} Z I Y Y A H A T-T A U J \bar{I} H I Y Y A H$ DALAM NOVEL $S Y A I^{\prime} U N$ F $\bar{I}$ SHADRI KARYA ICHSĀN ABDU AL-QUDDŪS: KAJIAN PRAGMATIK
}

Abdul Jawat Nur

jawatnur@ugm.ac.id

Sastra Arab, Departemen Bahasa dan Sastra

Fakultas Ilmu BudayaUniversitas Gadjah Mada

\begin{abstract}
This paper will describe al-af'āl al-injāziyyah at-taujīhiyyah or acts of directive illocution speech in the novel Syai'un fī Shadrī the work of Ichsān 'Abdu Al-Quddūs which is studied based on pragmatic studies. Novel Syai'un fì Shadrī is a novel classified as new (2016) in which many expressions containing acts of directive illocution speech. This is the reason for this research. To facilitate the course of research, this research through three strategic stages, namely data collection methods, data analysis methods, and methods of reporting the results of data analysis. Based on research that has been done concluded that in the novel SFS Ichsānby'Abdu Al-Quddūs is used various kinds of the act of directive illocution speech. They are (1) The act of saying thalabiyyah is a request to do or leave something, such as: rule 'amr', ask permission 'isti'zān ', suggests' iqtirāch', warns' tachdzī ', motivates' tasyjī' ', begs attention' tanbīh, threatens' tahdi $d^{\prime}$, prays'du' ${ }^{\prime}{ }^{\prime}$, swearing 'qasam' and (2) The act of nafsiyyah speech is a speech act related to psychological conditions, such as motivating, cursing, pitting, and joking.
\end{abstract}

Keywords: pragmatics, speech acts, phrases, al-af'āl al-injāziyyah at-taujīhiyyah.

$$
\begin{aligned}
& \text { ملخص } \\
& \text { تتناول هذه المقالة الأفعال الإنجازية التوجيهية فن رواية شيئ فى صدرى تأليف إحسان عبد القدوس دراسة تداولية. }
\end{aligned}
$$

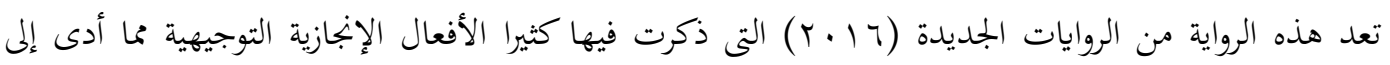

$$
\begin{aligned}
& \text { العمل بدراستها ـ وللوصول إلى غاية البحث ، يستخدم البحث ثلاث خطوات مهمة هي : جمع بيانات البحث } \\
& \text { ، ثم تحليلها ، ثم عرض نتائج البحث ـ وقد توصلت الدراسة إلى أن الرواية استخدمت أنواع الأفعال الإنجازية } \\
& \text { التوجيهية وهي : أولا ، أفعال الكلام الطلبية لطلب الفعل أو الكف مثل الأمر والاستئذان والاقتراح والتحذير } \\
& \text { والتشجيع والتنبيه والتهديد والدعاء والقسم ـ ثانيا ، أفعال الكلام النفسية وهي التى تتعلق بأحوال النفس مثل }
\end{aligned}
$$

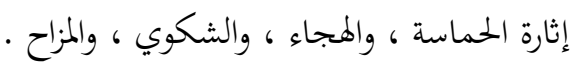

$$
\begin{aligned}
& \text { الكلمات المفتاحية : التداولية ، أفعال الكلام ، العبارات ، الأفعال الإنجازية التوجيهية . }
\end{aligned}
$$




\section{PENDAHULUAN}

Penelitian tentang at-tadāwul̄ atau pragmatik di dunia Arab merupakan arus baru dalam bidang penelitian linguistik. Hal ini seperti yang dikemukakan Sharrāf (2010:1) bahwa pragmatik merupakan mazhab baru yang memfokuskan studinya pada hubungan antara bahasa dan para pemakainya dengan semua aspeknya. Salah satu kajian pragmatik adalah tindak tutur yang dalam bahasa Arab disebut dengan al-af'āl al-kalāmiyyah.

Al-af'āl al-injāziyyah atau tindak tutur ilokusi merupakan salah satu jenis tindak tutur atau al-af'àl al-kalāmiyyah yang mempunyai posisi yang penting dalam studi pragmatik. Hal ini menarik minat para peneliti untuk meneliti bidang kajian pragmatik, seperti yang telah dilakukan Jalūlī (2006), Āminah (2011), Quthāf (2013), dan Nur (2016). Para peneliti tersebut mengkaji tindak tutur ilokusi dalam tuturan yang terdapat pada Alquran, naskah Arab Klasik, dan novel.

Al-af'āl al-injāziyyah at-taujīhiyyah atau tindak tutur ilokusi direktif (TTID) merupakan salah satu dari lima jenis tindak tutur ilokusi. Tindak tutur ini banyak digunakan, baik dalam bahasa lisan maupun bahasa tulis seperti dalam karya sastra. Pemakaian jenis tindak tutur ini juga digunakan dalam karya-karya sastra Arab. Salah satunya adalah TTID yang terdapat dalam novel SFS karya Ichsān 'Abdu Al-Quddūs (2016). Iḥān 'Abdu al-Quddūs (1 Januari 1919 - 11 Januari 1990) adalah seorang penulis, novelis, jurnalis, dan editor dalam surat kabar Al Akhbar lan Al-Ahram, dua surat kabar yang sangat terkenal di Mesir. Iatelah menulis ratusan novel dan antologi cerpen. Beberapa novelnya diadaptasi dalam drama radio dan film-film.I I̦sān 'Abdu al-Quddūs juga telah menerima beberapa penghargaan sastra, baik tingkat nasional maupun internasional (alQuddūs, 2016).

Novel Syai'un fī Shadrī (SFS) karya Ichsān 'Abdu Al-Quddūs (2016) dijadikan objek material penelitian ini karena beberapa alasan, yaitu (1) novel tersebut merupakan novel yang relatif baru yang diterbitkan pada 2016, (2) dalam novel tersebut banyak ditemukan tuturan-tuturan yang menggunakan TTID, (3) novel tersebut merupakan salah satu karya sastrawan Arab yang terkenal, yaitu Ichsān 'Abdu Al-Quddūs, dan (4) bahasa yang digunakan dalam novel tersebut adalah bahasa Arab Fushchā (ragam resmi) dan bahasa Arab Amiyah (ragam santai). Berdasarkan fungsinya, kedua ragam tersebut mempunyai perbedaan dalam penggunaannya. Bahasa Arab Fushchā merupakan bahasa Arab standar yang dipakai dalam situasi yang resmi, sedangkan bahasa Arab Amiyah merupakan bahasa Arab yang digunakan dalam situasi yang tidak resmi.

Berdasarkan penjelasan dan pernyataan tersebut, maka penelitian ini bertujuan untuk mendeskripsikan berbagai macamTTIDdan fungsinya dalam novel SFSkarya Ichsān 'Abdu Al-Quddūs. Oleh karena itu, penelitian ini diharapkan dapat memberikan sumbangan pemikiran terhadap kajian TTID bahasa Arab dalam menafsirkan gejala-gejala lingual yang muncul dalam novel SFSkarya Ichsān 'Abdu Al-Quddūs (2016).

Penelitian TTIDyang ada dalam novel SFS karya Ichsān 'Abdu Al-Quddūs ini memanfaatkan teori pragmatik. Menurut Wijana (1996: 1), pragmatik merupakan cabang ilmu bahasa yang mempelajari struktur bahasa secara eksternal, yaitu bagaimana satuan kebahasaan itu digunakan dalam komunikasi. Cruse (2000:16) via Cummings (2007:2) menyatakan bahwa pragmatik merupakan disiplin ilmu yang berkaitan dengan aspek informasi yang disampaikan melalui bahasa. Verhaar (2001: 14)juga menjelaskan, pragmatik adalah cabang ilmu linguistik yang membahas tentang apa yang termasuk struktur bahasa sebagai alat komunikasi antara penutur dan lawan tutur. Nadar (2008) mendefinisikan pragmatik sebagai cabang linguistik yang mempelajari 
bahasa yang digunakan untuk berkomunikasi dalam situasi tertentu. Sejalan dengan ketiga pendapat tersebut, Ash-Sharrāf (2010:3) mendefinisikan pragmatik sebagai kajian pemakaian bahasa dalam komunikasi. Oleh karena itu, hal ini berarti bahwa dalam pragmatik makna bukanlah sesuatu yang berkaitan dengan kata-kata saja, tetapi berkaitan dengan konteks penutur dan mitra tutur, serta situasi tuturan yang menurut Subroto (2011:11) disebut makna menurut yang dikehendaki penutur.

Berdasarkan pendapat-pendapat tersebut dapatlah dirumuskan bahwa pragmatik adalah cabang dari linguistik yang mengkaji satuan kebahasaan yang digunakan penutur dan mitra tutur dalam berkomunikasi berdasarkan konteksnya. Sehubungan dengan hal tersebut, Yule (1996: 4) menjelaskan bahwa hal yang dikaji dalam pragmatik antara lain adalah teori tindak tutur, prinsip kerjasama, implikatur percakapan, teori relevansi, dan prinsip kesopanan.

Berdasarkan penjelasan tersebut, maka penelitian ini memanfaatkan teori tindak tutur ilokusi, khususnya TTID sebagai bagian dari kajian pragmatik. Secara umum dapat dijelaskan bahwa tindak tutur merupakan gejala individual, bersifat psikologis, dan keberlangsungannya ditentukan oleh kemampuan bahasa para penutur dalam menghadapi peristiwa tertentu (Chaer, 2004:50). Adapun tindak tutur ilokusi adalah seperti yang disampaikan Wijana (1996: 18), yaitu tindak tutur untuk melakukan sesuatu. Sejalan dengan pendapat tersebut, tindak tutur ilokusi, menurut Chaer, (2004: 53) dan AshSharrāf (2010:41-43), adalah tindak tutur yang biasanya diidentifikasikan dengan kalimat performatif yang eksplisit. Tindak tutur ini biasanya berkaitan dengan pemberian ijin, mengucapkan terima kasih, menyuruh, menawarkan, dan menjanjikan. Dengan demikian, tindak tutur ini dapat juga digunakan untuk melakukan sesuatu (The Act of Doing Something) bila situasi tuturnya dipertimbangkan dengan cermat. Sebagai contoh dapat diberikan seperti tuturan (1) berikut.

$$
\begin{aligned}
& \text { (1) .... تجري الأيام مسرعة } 1 \text { (Tajrī al-ayyāmu musri'atan...../ } \\
& \text { (Asyīr, 2014:11). } \\
& \text { 'Hari-hari berlalu dengan cepat' }
\end{aligned}
$$

Tuturan (1) tersebut bila diucapkan oleh seorang ustazkepada para jama'ahnya ketika memberikan pengajian, tidak hanya berfungsi untuk memberitahukan sesuatu. Akan tetapi, tuturan tersebut juga mempunyai fungsi agar para jama'ahnya melakukan sesuatu, yaitu agar para jama'ah rajin beribadah dan menambah amal kebaikannya karena usianya semakin bertambah.

Nadar (2008:11), Ash-Sharrāf (2010: 205-248), dan Wijana (2010) membagi tindak tutur ilokusi menjadi lima macam, yaitu:

\section{a. Al-Ikhbāriyyāt atau asertif}

Tindak tutur asertif adalah tindak tutur yang digunakan untuk menyatakan fakta atau pengetahuan. Tuturan asertif ini dapat diverifikasi atau difalsifikasi kebenarannya pada waktu atau setelah tuturan itu diutarakan. Verba yang digunakan dalam tindak tutur deklaratif ini antara lain adalah arā 'Saya lihat', aktub 'Saya tulis', asma' 'Saya dengar', nattafiq 'Kami setuju', adrī'Saya mengerti', dll. (Ash-Sharrāf, 2010: 209).

b. Al-I'lāniyyāt atau deklaratif

Tindak tutur deklaratif adalah tindak tutur yang pelaksanaannya membuat sesuatu yang dinyatakan dalam tuturan terealisasi. Tuturan ini dinyatakan oleh orang yang mempunyai kedudukan tertentu sehingga orang-orang yang mendengar menyepakati dengan apa yang dinyatakannya. Verba yang digunakan dalam tindak tutur deklaratif ini antara lain adalah dalam tuturan: Anta churrun 'Anda bebas', zawwajtuki 'Saya nikahkan Anda' (Ash-Sharrāf, 2010: 209).

c. Al-Iltizāmiyyāt atau komisif 
Tindak tutur komisif adalah tindak tutur yang mengikat penuturnya untuk melakukan tindakan apa yang dijanjikan. Tindak tutur ini berkaitan dengan perjanjian, sumpah, ancaman, dll. Verba yang digunakan dalam tindak tutur komisif dalam bahasa Arab adalah seperti: aqsamtu billāh 'Saya berjanji demi Allah, sa'urāfiquk 'Saya akan menemanimu', satarauna bi anfusikum ba'da qalīl 'Kalian akan lihat sendiri akibatnya' (Ash-Sharrāf, 2010: 230).

d. At-Ta'bìriyyāt atau ekspresif

Tindak tutur ekspresif adalah tindak tutur yang digunakan untuk menyatakan sesuatu yang berhubungan dengan hal yang telah dilakukan penuturnya. Hal ini seperti tindak mengakui dan meminta maaf. Verba yang digunakan dalam tindak tutur ekspresif dalam bahasa Arab adalah seperti: Asykuru 'Saya berterima kasih', uchissu 'Saya merasa', a'taqidu 'Saya yakin' (Ash-Sharrāf, 2010: 231).

e. At-Taujīhiyyāt atau direktif

Tindak tutur direktif adalah tindak tutur yang diungkapkan penuturnya agar mitra tutur melakukan sesuatu. Verba yang digunakan dalam tindak tutur direktif dalam bahasa Arab adalah seperti: utruk 'tinggalkan', a'thi 'berikan', izhhab 'pergilah', jarrib 'cobalah', ibchats 'carilah', dll. (Ash-Sharrāf, 2010: 244).

Dari kelima macam tindak tutur ilokusi tersebut, penelitian ini hanya difokuskan pada tindak tutur ilokusi yang kelima, yaitu At-taujīhiyyāt atau tindak tutur direktif yang didasarkan pada pendapat Ash-Sharrāf(2010). AshSharrāf(2010: 244) memerikan tindak tutur direktif menjadi dua, yaitu thalabiyyah dan nafsiyyah. Tindak tutur thalabiyyah adalah permohonan untuk melakukan atau meninggalkan sesuatu, seperti: memerintah 'amr', minta ijin 'isti'dzān', menyarankan 'iqtirāch', memperingatkan 'tachdzīr', memotivasi 'tasyjì', memohon perhatian 'tanbīh', mengancam 'tahdìd', berdoa ' $d u$ 'a', bersumpah 'qasam', menasehati 'nusch', melarang 'nahy', berwasiat 'washiyyah', dan lain-lain. Adapun tindak tutur nafsiyyah merupakan tindak tutur yang berkaitan dengan kondisi psikologis seseorang ketika suatu tuturan diungkapkan, seperti memotivasi 'tasyji', memaki 'syatm', mengadu 'syakwā, mengeluh 'tazhallum', menenangkan 'thuma'nah', bersendagurau 'mizāch', introspeksi 'muchāsabah', dan lain-lain.

\section{PEMBAHASAN}

Berdasarkan analisis TTID yang telah dilakukan terhadap novel SFS karya Ichsān 'Abd Al-Quddūs(2016) dapatlah diketahui bahwa TTIDdalam novel tersebut adalah tindak tutur direktif thalabiyyah dan tindak tutur direktif nafsiyyah, seperti yang diuraikan dalam begian berikut.

\section{Tindak Tutur Direktif Thalabiyyah}

Tindak tutur direktif thalabiyyah merupakan tindak permohonan untuk melakukan atau meninggalkan sesuatu. Tindak tutur thalabiyyah dalam novel SFSkarya Ichsān 'Abd Al-Quddūs (2016) adalah tindak tutur memerintah 'amr', minta ijin 'isti'dzān', menyarankan 'iqtirāch', memperingatkan 'tachdzīr', memotivasi 'tasyjī', memohon perhatian 'tanbīh', mengancam 'tahdīd', berdoa ' $d u$ 'a', bersumpah 'qasam', melarang 'nahy', seperti dalam tuturan-tuturan berikut.

\section{a. Memerintah}

Tuturan memerintah merupakan salah satu jenis TTID thalabiyyah. Memerintah merupakan tindakan penutur melalui kata untuk menyuruh mitra tutur melakukan sesuatu (Sugono, 2008:799). Tindak tutur memerintah dalam novel SFSkarya Ichsān 'Abd Al-Quddūs (2016) adalah seperti pada tuturan (1) dan (2) berikut.

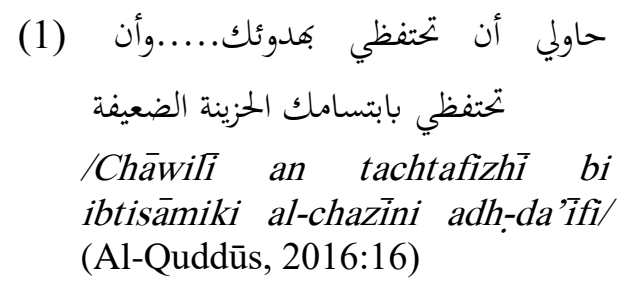


'Cobalah menjaga ketenanganmu....dan cobalah untuk menjaga senyummu yang sedikit sedih'

Tuturan (1) merupakan dialog antara tokoh Aku dengan kekasihnya, Hudā. Tokoh Aku memerintah Hudā agar kekasihnya itu tetap tenang dan tetap tersenyum walaupun hati kekasihnya itu sedang marah. Tuturan (1) tersebut mengandung tindak tutur direktif memerintah, yaitu tuturan chāwili 'cobalah (perempuan)!'Tujuan penutur mengungkapkan tuturan tersebut adalah memerintahkan mitra tuturnya agar tetap tenang dan tidak emosional dalam mengahadapi masalah. Penanda lingual chāwilī 'cobalah (perempuan)!' pada tuturan (1) tersebut menunjukkan bahwa ungkapan tersebut merupakan tindak tutur direktif memerintah.

(2)

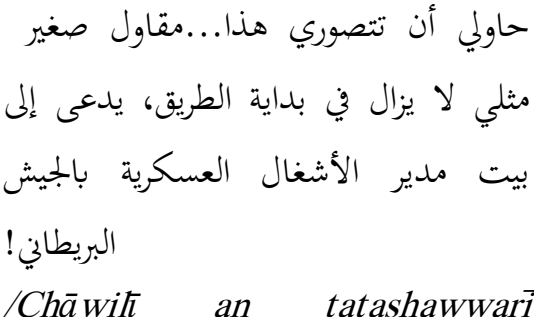

/Chāwi hādzā.... Muqāwilun shagīirun mitsti là yazālu fì bidàyati aththariqi, yud'a ila baiti mudiri alasygāli al-'askariyyah bi al-jaisyi al-Baritāniyyah!(Al-Quddūs, 2016:81).

'Cobalah menggambarkan hal ini..... seorang negosiator kecil sepertiku selalu menjadi penunjuk jalan, diundang ke rumah direktur operasional tentara di angkatan bersenjata Kerajaan Inggris’.

Tuturan (2) merupakan dialog antara tokoh Aku dengan Hudā, kekasihnya ketika tokoh Aku mendapat undangan pesta di rumah Kolonel David. Tokoh $\mathrm{Aku}$ sangat senang dengan undangan pesta tersebut, dan hal itu diceritakan kepada kekasihnya. Tuturan (2) tersebut mengandung TTID memerintah, yaitu tuturan chāwilī 'cobalah (perempuan)!'Tujuan ungkapan penutur tersebut adalah memerintahkan mitra tuturnya untuk membayangkan bahwa penutur sebagai pegawai rendahan diundang pesta oleh Kolonel David, direktur operasional tentara kerajaan Inggris. Ungkapan chāwilì 'cobalah (perempuan)!' pada tuturan (1) tersebut merupakan penanda bahwa ungkapan tersebut merupakan tindak tutur direktif memerintah.

\section{b. Meminta ijin 'isti'dzān'}

Minta ijin merupakan hal yang menyatakan boleh melakukan sesuatu atau minta kerelaan untuk mengabulkan (tidak melarang) (Sugono, 2008:390). Berdasarkan hal tersebut, tindak tutur meminta ijin adalah tindakan penutur melalui kata-kata yang disampaikan kepada mitra tutur agar diperkenankan melakukan sesuatu. Tindak tutur direktif meminta ijin dalam novel SFSadalah seperti pada tuturan (3) dan (4) berikut.

$$
\begin{aligned}
& \text { دعيني أقدم لك زوجتي الإنجليزية... } \\
& \text { وأقول: زوجتي الإنجليزية، ولا أقول: } \\
& \text { زوجتي فقد...لا أحد يقول أبدا: }
\end{aligned}
$$

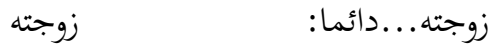

$$
\begin{aligned}
& \text { الإنجليزية... كأفم يتعمدون إهانتي!! } \\
& \text { IDa innì uqaddimu laki zaujatî } \\
& \text { al-Injiliziyyati...wa aqūlu: } \\
& \text { zaujatî al-Injiliziyyati, wa là } \\
& \text { aqūlu zaujatī faqad....là } \\
& \text { achada yaqūlu abadan!: } \\
& \text { Zaujatuhu...da'iman: } \\
& \text { Zaujatuhu al-injiliziyyah...ka } \\
& \text { annahum yata'ammadūna } \\
& \text { ihānatī/ (Al-Quddūs, } \\
& \text { 2016:73). } \\
& \text { 'Ijinkan aku menyampaikan } \\
& \text { kepadamu tentang istriku } \\
& \text { yang berkebangsaan } \\
& \text { Inggris....dan saya } \\
& \text { mengatakan, "Istriku orang } \\
& \text { Inggris". Dan saya tidak }
\end{aligned}
$$


mengatakan, "Istriku, saja". Tak seorangpun mengatakan, "Istrinya". Selamanya mereka mengatakan, "Istrinya orang Inggris". Seakan-akan mereka menghinaku.'

Tuturan (3) merupakan dialog antara tokoh Aku dengan anak perempuan temannya, ketika tokoh Aku ditanya tentang istrinya. Tokoh $\mathrm{Aku}$ yang merupakan penduduk asli Mesir merasa dihina oleh orang-orang di sekitarnya karena istrinya berkebangsaan Inggris. Hal ini menyebabkan tokoh Aku meminta ijin kepada anak perempuan temannya itu untuk menjelaskannya. Tuturan (3) tersebut merupakan jenis TTIDmeminta ijin, yaitu tuturan $d a$ 'în $\bar{\imath}$ 'ijinkan aku (perempuan)!'Tujuan ungkapan penutur tersebut adalah meminta ijin kepada mitra tuturnya untuk menjelaskan perihal istrinya. Ungkapan da'īn̄ 'ijinkan aku (perempuan)!' pada tuturan (1) tersebut merupakan penanda bahwa ungkapan tersebut merupakan tindak tutur direktif meminta ijin.

$$
\begin{aligned}
& \text { هل استعدت ابتسامتك قبل أن تستميري في قراءة (4) } \\
& \text { خطابي الطويل؟ إذن.... دعيني أناديك مرة } \\
& \text { ثانية: حبيبتي هدى! }
\end{aligned}
$$

/Hal ista'dadti ibtisāmaki qabla an tastamît $\bar{i}$ fi qirà'ati khitāa $\bar{i}$ ath-thawili? Idzan...da ìn̄i unādiki marratan tsāniyatan: Habīibati Hudā! (Al-Quddūs, 2016:15).

'Apakah kamu sudah mempersiapkan senyumanmu sebelum kamu melanjutkan membaca suratku yang panjang?...Kalau begitu...ijinkan aku untuk memanggilmu sekali lagi, "Kekasihku Hudā!".

Tuturan (4) tersebut mengandung tindak tutur direktif meminta ijin. Tuturan tersebut merupakan dialog antara tokoh Aku dengan kekasihnya, Hudā ketika tokoh Aku menyampaikan surat cintanya yang panjang kepada kekasihnya. Tuturan (3) tersebut merupakan jenis TTIDmeminta ijin, yaitu tuturan $d a$ 'in $\bar{\imath}$ 'ijinkan aku (perempuan)!'Tujuan ungkapan penutur tersebut adalah meminta ijin kepada mitra tuturnya untuk menegaskan sekali lagi bahwa kekasishnya hanyalah Hudā. Ungkapan da' '̄n̄ 'ijinkan aku (perempuan)!' pada tuturan (4) tersebut merupakan penanda lingual bahwa ungkapan tersebut merupakan tindak tutur direktif meminta ijin.

\section{c. Memperingatkan 'tanbīh'}

Menurut (Sugono, 2008:433), memperingatkan berarti memberi peringatan berupa nasihat atau teguran supaya ingat akan kewajibannya. Dengan demikian dapatlah dikatakan bahwa tindak tutur memperingatkan adalah tindak tutur yang disampaikan oleh penutur kepada mitra tutur untuk memberi peringatan berupa nasihat, teguran mitra tutur ingat akan kewajibannya dan tidak melakukan tindakan yang negatif. Tindak tutur direktif memperingatkan dalam novel SFSadalah seperti pada tuturan (5) berikut.

(5)

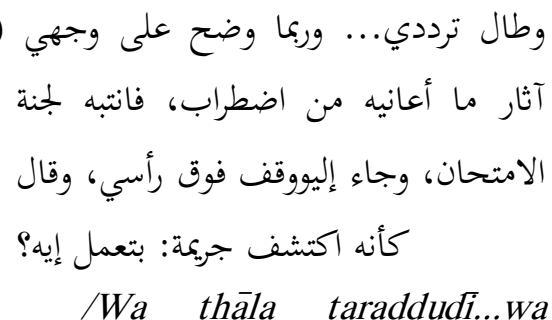
rubbamā wadhacha 'alā wajhì àtsāru mā 'u'ānīhi min idhthirābin, fantabaha lajnatu al-imtichāni. Wa jā'a ilayya, wa waqafa fauqa ra'sí, wa qāla ka'annahu iktasyafa jarimatan: Bitta'ammal īh?/(Al-Quddūs, 2016:26).

'Aku semakin bingung...Barangkali di wajahku tampak jelas kebingunganku, panitia ujian memperingatkanku. Dia 
mendatangiku dan berhenti di atas kepalaku. Dia bertanya kepadaku seakan-akan seperti menginterogasi seorang penjahat, "Kamu sedang melakukan apa?"

Tuturan (5) di atas merupakan tuturan yang mengandung tindak tutur direktif memperingatkan. Tuturan tersebut merupakan dialog antara tokoh Aku dengan ia spengawas ujian ketika tokoh Aku mengerjakan soal-soal ujian di kelas. Tokoh Aku sangat bingung karena dia kesulitan mengerjakan soal-soal ujian. Sementara itu, dia telah menyiapkan contekan di saku celananya. Ketika tangannya mengeluarkan contekan dari sakunya, pengawas ujian mengetahui hal itu dan memperingatkannya. Tuturan (5) tersebut merupakan jenis TTIDmemperingatkan, yang diungkapkan dengan tuturan Bitta'ammal īh? 'Apa yang sedang kamu lakukan?'.Tujuan ungkapan penutur tersebut adalah memperingatkan mitra tuturnya untuk tidak mencontek dalam ujian. Ungkapan Bitta'ammal ìh? 'Apa yang sedang kamu lakukan?' pada tuturan (5) tersebut merupakan penanda lingual bahwa ungkapan tersebut merupakan tindak tutur direktif memperingatkan.

\section{d. Melarang 'nahy'}

Melarang adalah tindakan penutur untuk memerintahkan mitra tutur supaya tidak melakukan sesuatu atau tidak memperbolehkan mitra tutur berbuat sesuatu (Sugono, 2008:640). Berkaitan dengan hal tersebut, maka tindak tutur melarang adalah tindak tutur yang disampaikan oleh penutur untuk mencegah mitra tutur melakukan sesuatu atau tidak memperbolehkan mitra tutur berbuat sesuatu. Tindak tutur melarang dalam novel SFSkarya Ichsān 'Abd AlQuddūs adalah seperti pada tuturan (6) berikut.

(6)

$$
\begin{aligned}
& \text { لاتدعيني مفاجأة ترسمين هذه الخطوط العميقة فوق } \\
& \text { وجهك الجميلة }
\end{aligned}
$$

LLà tad'inī mufaja'atan tarsumina hādzihi al-khuthüthi al-'amiquati fauqa wajhiki al-jamīlah/ (AlQuddūs, 2016: 15).

'Janganlah kamu mengundangku dengan tiba-tiba untuk menggambar garis-garis yang dalam di atas wajahmu yang cantik'

Tuturan (6) merupakan tuturan yang termasuk tindak tutur direktif melarang. Tuturan tersebut diungkapkan oleh tokoh Aku untuk melarang kekasihnya secara tiba-tiba untuk datang. Hal ini disebabkan tokoh aku merupakan orang yang bekerja di angkatan perang Inggris dan mempunyai tugas yang banyak. Tuturan (6) termasuk tindak tutur direktif melarang ditandai dengan penanda lingual La tad'in̄i 'janganlah kamu mengundangku'.

\section{e. Doa ' $d u$ ' $\bar{a}$ '}

Doa merupakan permohonan (harapan, pujian) kepada Tuhan (Sugono, 2008:255). Dengan demikian, tindak tutur direktif doa adalah ungkapan penutur untuk memohon sesuatu kepada Tuhan, baik hal itu ditujuakan kepada dirinya sendiri maupun untuk orang lain. TTID doa dalam novel SFSkarya Ichsān 'Abd Al-Quddūs adalah seperti pada tuturan (7) dan (8) berikut.

$$
\begin{aligned}
& \text { (7).... الله ينور عليك يا أختي } \\
& \text { /Allāhu yunawwiru 'alaiki yā } \\
& \text { ukhtī/(Al-Quddūs, 2016:230). } \\
& \text { 'Semoga Allah memberikan } \\
& \text { cahayanya kepadamu, Saudariku' }
\end{aligned}
$$

Tuturan (7) tersebut merupakan tuturan mengandung tindak tutur direktif doa. Tuturan tersebut diungkapkan oleh 'Abd al-'Azhīm kepada saudara perempuannya yang sudah meninggal. 'Abd al-'Azhīm memohon kepada Tuhan agar saudara 
perempuannya itu diberi cahaya di alam kubur. Tuturan (7) tersebut merupakan jenis TTID doa, yaitu dalam tuturan Allāhu yunawwiru 'alaiki 'Semoga Allah memberikan cahayanya kepadamu'.Tujuan ungkapan penutur tersebut adalah meminta atau memohon kepada Tuhan agar Tuhan memberikan cahaya kasih sayang-Nya kepada saudara perempuan penutur di alam kubur. Ungkapan Allāhu yunawwiru 'alaiki 'Semoga Allah memberikan cahayanya kepadamu' dalam tuturan (7) tersebut merupakan tindak tutur direktif doa.

يا رب.....يا رب توب علي! (8)

/Yà Rabbi...yā Rabbi tūb 'alayya! (Al-Quddūs, 2016: 466).

'Wahai Tuhanku...wahai

Tuhanku...ampunilah hambamu ini!'

Tuturan (8) tersebut merupakan tuturan mengandung tindak tutur direktif doa. Tuturan tersebut diungkapkan oleh tokoh Ibu kepada anak perempuannya ketika mereka sedang membicarakan masalah pernikahan anaknya itu. Tokoh Ibu mengatakan bahwa setelah menikah, Khairiyyah--anak perempuannya itudiminta ibunya untuk pindah ke wilayah Syabrā. Akan tetapi, Khairiyyah tidak mau menuruti keinginan ibunya tersebut. Khairiyyah masih ingin tinggal bersama orang tuanya. Hal itu membuat ibunya marah dan dia mengungkapkan doa, memohon ampunan kepada Tuhan atas kemarahannya kepada Khairiyyah. Tuturan (8) tersebut merupakan jenis TTIDdoa, yaitu dalam tuturan yā Rabbi tūb 'alayya! 'Wahai Tuhanku...wahai Tuhanku...ampunilah hambamu ini!'. Tujuan ungkapan tokoh Ibu sebagai penutur adalah meminta atau memohon kepada Tuhan agar Tuhan mengampuni kesalahannya karena telah memarahi Khairiyyah, anak perempuannya. Ungkapan yā Rabbi tūb 'alayya! 'Wahai Tuhanku...wahai Tuhanku....ampunilah hambamu ini!'dalam tuturan (8) tersebut merupakan tindak tutur direktif doa yang ditandai dengan penanda lingual penyebutan $y \bar{a}$ Rabbi 'wahai Tuhanku' dan ungkapan permohonan tüb 'alayya 'ampuni dosa dan kesalahanku'.

\section{f. Mengancam 'tahdīd'}

Mengancam adalah menyatakan maksud (niat, rencana) untuk melakukan sesuatu yang merugikan, menyulitkan, menyusahkan, atau mencelakakan pihak lain (Sugono, 2008:62). Dengan demikian dapatlah dikatakan bahwa tindak tutur mengancam adalah tindakan penutur kepada mitra tutur yang merugikan, menyulitkan, menyusahkan, atau mencelakakan mitra tutur. TTID mengancam dalam novel SFSadalah seperti pada tuturan (9) berikut.

$$
\begin{aligned}
& \text { وما كدت أسمع كلماته حتى ثرت... ووقف صارخا } \\
& \text { بأعلى صوتي وأنا أنتفض: ومات كلماته }
\end{aligned}
$$

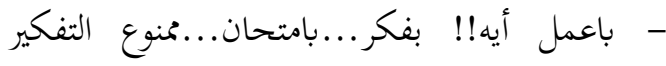

$$
\begin{aligned}
& \text { كمان. إنتم عايزينا نسقط...... }
\end{aligned}
$$

/Wa ma kidtu asma'u kalimātihi chattā tsarrat....wa waqafa shārikhan bi'a'lā shautī wa ana antafidhu:

- Ba'mal

ìh!!...bifakar...bimtichān....mamn

$\bar{u}$, at-tafkir kamān. Intum 'àyizinā nasquth(Al-Quddūs, 2016:26).

'Saya hampir tidak mendengarkan kata-katanya yang serak...Dia berdiri sambil berteriak dengan tinggi daripada suaraku:

-“Apa yang kamu kerjakan !!....Pikirkan ..ini ujian...Dilarang berpikir lagi. Jika kamu berbuat curang, nilaimu akan jatuh......'

Tuturan (9) tersebut merupakan tuturan yang mengandung tindak tutur direktif mengancam. Tuturan tersebut merupakan dialog antara tokoh Aku dengan pengawas ujian ketika tokoh Aku kesulitan mengerjakan soal-soal ujian. 
Tokoh Aku melihat teman-temannya dengan tenang mengerjakan soal, sementara dia masih kebingungan mencermati soal ujian. Tokoh Aku berkali-kali ingin mengeluarkan contekan yang ia simpan di saku celananya. Hal itu membuat pengawas ujian curiga dan mendekatinya sambil mengancam ke tokoh Aku. Pengawas ujian mengancam tokoh Aku bahwa jika dia berbuat curang maka dia akan gagal dalam ujian. Tuturan (9) tersebut merupakan jenis TTID mengancam, yang diungkapkan dengan tuturan Intum 'àyizina nasquth 'Jika kamu berbuat curang, nilaimu akan jatuh.' Tujuan ungkapan pengawas ujian tersebut adalah mengancam mitra tuturnya untuk tidak berbuat curang dalam ujian. Ungkapan Intum 'àyiziñā nasquth 'Jika kamu berbuat curang, nilaimu akan jatuh' pada tuturan (9) tersebut merupakan penanda lingual bahwa ungkapan tersebut merupakan tindak tutur direktif mengancam.

\section{g. Menyarankan 'iqtirāch'}

Menurut Sugono (2008:1268), menyarankan berarti memberikan saran, anjuran yang dikemukakan untuk dipertimbangkan. TTID menyarankan adalah ungkapan penutur untuk memberikan saran, anjuran kepada mitra tutur untuk dipertimbangkan. Dalam novel SFS, TTID menyarankan adalah seperti pada tututan (10) berikut.

$$
\text { قلت: قال: طبعا....طبعا يا باشا معروف بلاش تقول لمدى ولا أمها }
$$

/Qultu: wa'mal ma'rūf balāsy ta'ūl li Hudā wa lā ummihā

Qàla: Thab'an...Thab'an yà Bāsyā(Al-Quddūs, 2016:541).

'Aku berkata: "Lakukanlah apa yang Anda ketahui, jangan Anda katakan kepada Hudā dan ibunya" Bāsyā’’

Dia menjawab: "Tentu...tentu,

Tuturan (10) merupakan dialog antara tokoh Aku dengan tokoh dokter. Tokoh

Aku menyarankan dokter agar dia tidak memberitahukan ke Hudā dan ibunya perihal penyakit yang diderita Hudā. Hal ini tokoh Aku maksudkan agar Hudā dan ibunya tidak mengkhawatirkan penyakit yang diderita Hudā, dan dokter pun menerima saran tokoh Aku tersebut. Tuturan (10) tersebut mengandung TTID menyarankan yang ditandai dengan tuturan menyarankan wa'mal ma'rüf balāsy ta'ūl li Hudā wa là ummihā Lakukanlah apa yang Anda ketahui, jangan Anda katakan kepada Hudā dan ibunya.

\section{h. Bersumpah 'qasam'}

Sumpah adalah pernyataan yang diucapkan secararesmi dengan bersaksi kepada Tuhan ataukepada sesuatu yang dianggap suci untuk menguatkankebenaran dan kesungguhannya(Sugono, 2008:1387). Berdasarkan definisi tersebut dapatlah dikatakan bahwa tindak tutur bersumpah berarti pernyataan penutur secara resmi dengan bersaksi kepada Tuhan untuk menguatkan kebenarannya kepada mitra tutur. TTID bersumpah dalam novel SFS adalah seperti pada tuturan (11) berikut ini.

$$
\begin{aligned}
& \text { والله دي حاله غريبه...يمكن تكون من تأثير (11) } \\
& \text { شدة الحمى... حاله شاذه عمري ما صادفه فس } \\
& \text { حياتي...وانا دلوقت باكتب بحث عن الحاله } \\
& \text { دي وحابعته لجمعية الأطباء في لندن. ... } \\
& \text { /Wallāhi dìālah } \\
& \text { garíbah.....yumkin takun min ta'tsir } \\
& \text { syiddati al-chumā....hachlah } \\
& \text { syādzah 'umrī mā shādafah fas } \\
& \text { chayāti..wa ana dilwa' baktub } \\
& \text { batchts 'an al-chālah di wa } \\
& \text { chab'athu lijam'iyyah al-athibbā' fi } \\
& \text { Lundun/ (Al-Quddūs, 2016:541). } \\
& \text { 'Demi Allah, ini adalah kondisi } \\
& \text { yang aneh...mungkin karena } \\
& \text { pengaruh demam yang } \\
& \text { hebat...kondisi yang aneh sepanjang } \\
& \text { hidupku...dan saya sekarang akan }
\end{aligned}
$$


menulis hasil pemeriksaan ini dan akan saya kirimkan ke perhimpunan dokter yang ada di London...'

Tuturan (11) merupakan sumpah yang diucapkan oleh tokoh dokter kepada mitra tuturnya ketika dia memeriksa penyakit yang diderita Hudā. Tokoh dokter merupakan seorang dokter yang sudah berpengalaman. Akan tetapi, dia menemukan gejala penyakit yang aneh ketika memeriksa Hudā yang sedang sakit. Oleh karena itu, dia bersumpah bahwa yang dia temukan itu merupakan gejala penyakit yang tidak biasa, dan dia akan mengirimkan hasil diagnosanya itu ke perhimpunan dokter yang ada di London. TTID bersumpahdalam tuturan (11) tersebut ditandai dengan ungkapan sumpah wallāhi 'Demi Allah'.

\section{Tindak Tutur Nafsiyyah}

Tindak tutur nafsiyyah merupakan tindak tutur yang berkaitan dengan kondisi psikologis. Tindak tutur ilokusi nafsiyyah dalam novel SFSadalah tindak bersenda gurau 'mizāch', memotivasi 'tasyjī', memaki 'syatm', dan mengadu 'syakwā', seperti yang akan diuraikan pada bagian berikut.

\section{a. Bersenda gurau ' $m i z \bar{a} c h$ '}

Bersenda gurau adalah bermainmain dengan kata-kata atau bercanda, seperti berkelakar, berseloroh, mengolokolok (Sugono, 2008:1309). Dengan demikian dapatlah dikatakan bahwa tindak bersenda gurau merupakan tindakan penutur dengan kata-kata kepada mitra tutur bertujuan untuk bercanda atau mengolok-olok. TTID nafsiyyah bersenda gurau dalam novel SFSadalah seperti pada tuturan (12) berikut.

$$
\begin{aligned}
& \text { وضحكت ضحكة بلا صوت، ثم رفعت إبريق الشاي } \\
& \text { وصبت منه في الفنجال....... } \\
& \text { إنه ليس شايا } \\
& \text { إنه ويسكي }
\end{aligned}
$$

$$
\begin{aligned}
& \text { ونظرت إليها بعينين متسعين، وقلت في } \\
& \text { دهشة: } \\
& \text { إيه ده...إنه ده يا تفيده؟ }
\end{aligned}
$$

/Wa dhachikat dhachkatan bilā shautin, tsumma rafa'at ibriqa asy-syaiyyi wa shabbat minhu fi al-finjāl.....

- Innahu Tis syāyā

- Innahu wiski

Wa nazartu ilaihā bi'ainaini muttasi'aini, wa qultu fï dihsyatin:

-Ih dah

- Innahu dah, yāYufídah?(AlQuddūs, 2016:445).

'Dia tertawa tanpa bersuara, kemudian dia mengangkat ceret teh dan menuangkannya di cangkir.

- Itu bukan teh.

- Itu wiski..

Aku menatapnya dengan kedua mataku terbelalak. Aku berkata dengan heran:

- Ini apa?

- Sesungguhnya itu apa, wahai Yufidah?

Tuturan (12) merupakan tuturan yang mengandung tindak tutur direktif bersendagurau. Tuturan tersebut merupakan dialog antara tokoh Aku dengan kekasihnya. Tokoh Aku menggoda kekasihnya dengan ungkapan Itu bukan teh. Itu wiski. Hal itu membuat kekasihnya kebingungan antara percaya bahwa yang dia tuangkan ke cangkir itu teh atau wiski. Oleh karena itu, kekasihnya bertanya ke tokoh Aku tentang minuman yang ada di teko itu. Tuturan (12) tersebut merupakan jenis TTIDbersenda gurau, yang diungkapkan dengan tuturan Innahu Iis syāyā. Innahu wiskl' Itu bukan teh. Itu wiski'. Tujuan ungkapan penutur bersenda gurau dengan mitra tuturnya tersebut adalah menggoda mitra tuturnya. Dengan demikian dapatlah dikatakan bahwa tuturan (12) tersebut merupakan tindak tutur direktif bersenda gurau. 


\section{b. Memotivasi 'Tasyjī',}

Memotivasi adalah memberikan usaha yang dapat menyebabkan seseorang atau kelompok orang tertentu tergerak melakukan sesuatu karena ingin mencapai tujuan yang dikehendakinya atau mendapat kepuasan dengan perbuatannya (Sugono, 2008:973). Sehubungan dengan hal tersebut, maka tindak memotivasi adalah usaha penutur untuk menggerakkan mitra tutur melakukan sesuatu untuk mencapai tujuan yang dikehendakinya. Tindak tutur direktif dalam novel SFSadalah seperti pada tuturan (13) berikut.

$$
\begin{aligned}
& \text { قال الضابط في هدوء: إن الثورة لا } \\
& \text { تنوي الاستيلاء على الشركة ، بل }
\end{aligned}
$$

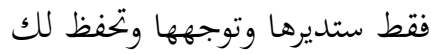

$$
\begin{aligned}
& \text { كل حقوقك فيها }
\end{aligned}
$$

/Qāla adh-Dhābitu bi alhudū'in: Inna ats-tsaura là tanwì al-istilā'a 'alà asysyirkati, bal faqad satudiruhā wa tawajjahuha wa tahfazu laka kulla chuqūqika fỉhā (Al-Quddūs, 2016:616).

'Petugas itu berkata dengan tenang: "Sesungguhnya revolusi tidak bermaksud untuk merebut perusahaan, tetapi hanya akan mengelola,mengarahkan, dan menjaga semua hak-hak Anda"

Tuturan (13) merupakan dialog antara tokoh petugas dengan tokoh Aku ketika tokoh Aku menghadap tokoh petugas di kantornya. Tokoh Aku sebelumnya meragukan adanya revolusi yang akan terjadi di Mesir dan bagaimana dampaknya. Berkaitan dengan hal itu, tokoh petugas memberikan motivasi kepada tokoh Aku bahwa revolusi itu akan berdampak positif terhadap kehidupan individu di Mesir.

\section{c. Memaki'Syatm'}

Memaki adalah mengeluarkan katakata(ucapan) keji (kotor, kasar) sebagai pelampiasankemarahan atau rasa jengkel(Sugono, 2008:902). Berdasarkan pengertian tersebut, tindak tutur memaki berarti ungkapan kasar, kotor penutur sebagai pelampiasan kemarahannya kepada mitra tutur. Dalam novel SFSjuga ditemukan tindak tutur direktif memaki, seperti pada tuturan (14) berikut.

$$
\text { يا بجنون...يا بجنون إيه ده...جرا إيه (14) }
$$

في عقلك؟!

/Yà magnūn..ya magnūn ìh dah....garā īh fí aa'lik?! (AlQuddūs, 2016:526).

'Dasar gila...orang gila, apa ini?... apa yang kamu pikirkan?!'

Tuturan (14) merupakan dialog antara tokoh Aku dengan kekasihnya ketika tokoh Aku mengunjungi kekasihnya. Mereka bercengkerama di kamar kekasih tokoh Aku. Karena terpengaruh minuman keras, tokoh Aku membuka dengan paksa baju kekasihnya bagian atas. Hal ini menyebabkan kekasih tokoh Aku marah dan memaki tokoh Aku dengan ungkapan Yà majnūn 'Orang gila'. Gila dalam tuturan (14) merupakan makian yang diungkapkan penutur kepada mitra tutur. Ungkapan 'gila' tersebut digunakan penutur untuk menggambarkan kelakuan mitra tutur seperti orang gila. Ungkapan 'gila' dari penutur yang ditujukan kepada mitra tutur tersebut berfungsi sebagai umpatan.

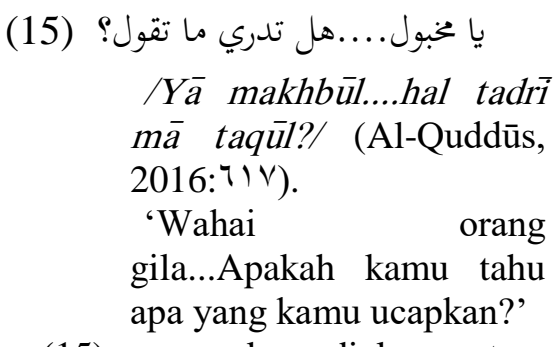

Tuturan (15) merupakan dialog antara tokoh Aku (mitra tutur) dengan kekasihnya (penutur) ketika mereka 
bertemu di sebuah kafe. Tokoh Aku mempunyai kebiasaan yang kurang baik, yaitu suka minum minuman keras. Ketika tokoh Aku mabok, dia tidak bisa mengontrol kata-kata yang dia sampaikan kepada kekasihnya, sehingga kekasihnya memaki tokoh Aku dengan yā makhbūl ...hal tadrī mā taqūl? 'wahai orang gila...apakah kamu tahu dengan apa yang kamu ucapkan?' Gila dalam tuturan (15) merupakan makian yang diungkapkan penutur kepada mitra tutur. Ungkapan 'gila' tersebut digunakan penutur untuk menggambarkan kelakuan mitra tutur seperti orang gila. Tuturan 'gila' dari penutur yang ditujukan kepada mitra tutur tersebut berfungsi

sebagai umpatan.

Referensi makian dalam tuturan (14) dan (15), menurut Wijana dan Rohmadi (2010) termasuk referensi keadaan, karena keadaan tokoh Aku digambarkan seperti orang gila. Adapun fungsi makian dalam tuturan (14) dan (15) tersebut, menurut Anderson dan Trudgill (1983:15),merupakan fungsi bahasa makian untuk mengekspresikan kemarahan.

\section{d. Mengadu 'Syakwā'}

Mengadu adalah mengajukan suatu perkara kepadaorang lain (Sugono, 2008:14). Tindak tutur mengadu berarti tindakan penutur berupa ungkapan tentang sesuatu kepada mitra tutur. Dalam novel SFSditemukan tindak tutur mengadu, seperti pada tuturan (16) berikut.

$$
\begin{aligned}
& \text { شكوت مرة من حذائي عقب الغداء، }
\end{aligned}
$$

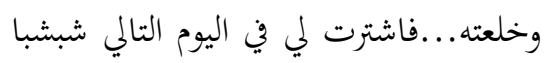

$$
\begin{aligned}
& \text { واحتفظت به في بيتها } \\
& \text { SSyakautu marratan min } \\
& \text { chidzā'i 'aqba al-gadā'i, wa } \\
& \text { khala'tuhu.... fastarat } I i \text { fi al- } \\
& \text { yaumi at-tāi syibsyiban } \\
& \text { wachtafazhtu bihi fì baitihāa(Al- } \\
& \text { Quddūs, 2016:278). }
\end{aligned}
$$

sepatuku....Pada suatu hari dia membelikanku sandal dan saya simpan di rumahnya'.

Tuturan (16) merupakan pengaduan tokoh Aku yang dia sampaikan ke tokoh Ibu tentang sepatunya yang sudah usang. Tokoh Aku merasa tidak nyaman dengan sepatunya. Dia sudah minta istrinya untuk membelikan sepatu sebagai pengganti spatu yang lama, tetapi istrinya tidak mau membelikannya. Hal itu sudah beberapa kali dia sampaikan ke istrinya. Karena istrinya tidak menanggapi permintaannya, maka dia mengadukan masalah tersebut ke ibunya, walaupun akhirnya dia dibelikan sandal oleh istrinya. Tuturan (16) tersebut mengandung TTID mengadu yang ditandai dengan tuturan Syakautu 'Aku mengadu'.

\section{KESIMPULAN}

Berdasarkan

keterangan, penjelasan, dan analisis yang telah dikemukakan dapatlah disimpulkan bahwa di samping digunakan dalam bahasa lisan, TTID juga digunakan dalam bahasa tulis, seperti dalam karya sastra Arab genre novel.

Novel SFS merupakan novel karya Ichsān 'Abdu Al-Quddūs yang terbit pada 2016. Bahasa yang digunakan dalam novel tersebut adalah bahasa Arab Fushchā dan bahasa Arab Amiyah. Hal ini memberikan gambaran bahwa secara sosiolinguistis, bahasa Arab Fushchā digunakan untuk menjelaskan jalannya cerita dan dialog antara para tokohyang terpelajar dan memiliki strata sosial yang tinggi. Sementara itu, bahasa Arab Amiyah digunakan dalam dialog para tokoh yang tingkat sosialnya rendah dan kurang terpelajar.

Dalam novel SFS banyak ditemukan tuturan yang mengandung TTID. TTID tersebut tersebut adalah(1) Tindak tutur thalabiyyah yaitu permohonan untuk melakukan atau meninggalkan sesuatu, seperti: memerintah 'amr', minta ijin 'isti'dzān', menyarankan 'iqtirāch', memperingatkan 
'tachdzīr', memotivasi 'tasyjī', memohon perhatian 'tanbīh', mengancam 'tahdīd', berdoa 'du'a', bersumpah 'qasam' dan (2) Tindak tutur nafsiyyah merupakan tindak tutur yang berkaitan dengan kondisi psiklogis, seperti memotivasi, memaki, mengadu, mengeluh, dan bersendagurau.

\section{DAFTAR PUSTAKA}

'Abdu Al-Quddūs, Ichsān, 2016. Syai 'un fì Shadrī. Kairo: ad-Dāru alMishriyyah al-Lubnāniyyah.

Anderson, L.G dan P.Trudgill. 1990. Bad Language. Oxford: Blackwell.

Āminah, 2011. Al-Af'al al'Kalāmiyyah Fī Sürah Al-Kahfi: Dirāsah Tadāwuliyyah. Tesis Magister Fakultas Bahasa dan Sastra Universitas Manturi, Tunis.

Asyīr, 'Abdullāh an-Nimsyī, 2014. Achbabtuka Aktsara Min Mā Yanbagī. Beirut: Dār al-Fārabì.

Berliana, Nita Kumalasari, 2013. "Tindak Tutur Direktif Pada Iklan Sepeda Motor di Boyolali'. Program Studi Pendidikan Bahasa, Sastra Indonesia, dan Daerah, Fakultas Keguruan dan Ilmu Pendidikan,Universitas Muhammadiyah Surakarta

Chaer, Abdul dan Leoni Agustina, 2004. Sosiolinguistik Perkenalan Awal. Jakarta: Rineka Cipta.

Chejne, Anwar G., 1996. Bahasa Arab dan Peranannya dalam Sejarah (The Arabic Language: Its Role in History). Jakarta: Pusat Pembinaan dan Pengembangan Bahasa.

Crystal, David, 1992. The Cambridge Encyclopedia of Language. New York: Cambridge University Press.
Cummings, Louise, 2007. Pragmatik Sebuah Perspektif Multidisipliner. Terjemahan "Pragmatics, A Multidisciplinary Perspective", (1999). Yogyakarta: Pustaka Pelajar.

Dian, Etikasari, 2012. “Tindak Tutur Direktif Dalam Wacana Kelas (Kajian Mikroetnografi Terhadap Bahasa Guru)". Skripsi Jurusan Sastra Indonesia Program Studi pendidikan Bahasa, Sastra Indonesia, dan Daerah Fakultas Sastra Universitas Negeri Malang.

Kesuma, Tri Mastoyo Jati, 2007. Pengantar (Metode) Penelitian Bahasa. Yogyakarta: Carasvatibooks.

Kridalaksana, Harimurti, 1993. Kamus Linguistik. Jakarta: Gramedia Pustaka Utama.

Maqfiroh, Oktavia. 2014. "Tindak Tutur Ilokusi Direktif dalam Anime Tonari NoTotoro Karya Hayao Miyazaki”. Program Studi Sastra Jepang, Universitas Brawijaya.

Nadar, F.X., 2008. Pragmatik dan Penelitian Pragmatik. Yogyakarta: Graha Ilmu.

Nur, Abdul Jawat, 2016. “Al-'Af'āl alInjāziyyah dan Novel Achbabtuka Aktsara Min Mā Yanbaghī Karya "Atsir Abdullah an-Nimsyi" dalam Jurnal Center of Middle Eastern Studies Vol. IX No.2 Edisi Juli-Desember 2016. Surakarta: Program Studi Sastra Arab, Fakultas Ilmu Budaya UNS.

Poerwadarminto, WJS. 1987. Kamus Umum Bahasa Indonesia. Jakarta: Pusat Pembinaan dan Pengembangan Bahasa Departemen Pendidikan dan Kebudayaan. 
Quthāf, 2013. Al-Khithāb As-Sardì Fì Kitāb Kalilah wa Dimnah Li Ibn Muqaffa'Muqārabah

Tadāwuliyyah. Jāmi'ah Al-Chajj Likhudhr Bānth,Tunis.

Raditya, Reza. 2014. "Fungsi Tindak Tutur Direktif Dalam Film Final Fantasy VII Advent Children: Complete." Program Studi Sastra Jepang, Universitas Brawijaya.

Ash-Sharrāf, Ali Muchammad Chajji, 2010. Al-Af'āl Al-Injāziyyah $F \bar{i}$ Al-'Arabiyyah Al-Mu'āshirah Dirāsatun Dilāliyyatun wa Mu’jamun Siyāqiyyun. Kairo: Maktabah Al-Adab.

Șini, Ismail, dkk. Tt. Al-'Arabiyyah Li An-Nāsyi'in Manhaj Mutakāmil Ligairi An-Näthiqīna bi Al'Arabiyyati. Bait Az-Zakāt alKuwaitī.

Subroto, Edi. 2011. Pengantar Studi Semantik dan Pragmatik (Buku 1. Pengantar Studi Semantik). Surakarta: Cakrawala Media.

Sudaryanto, 1993. Metode dan Teknik Analisis Bahasa Pengantar Penelitian Wahana Kebudayaan Secara Linguistis. Yogyakarta: Duta Wacana University Press.

Sugono, Dendy, 2008. Kamus Bahasa Indonesia. Jakarta: Pusat Bahasa.

Wahbah, Majdi, 1984. Mu’jamu alMusthalachät al- 'Arabiyyah Fì alLugah wa al-Adab. Beirut: Maktabah Lubnan.

Wijana, I Dewa Putu, 1996. Dasar-dasar Pragmatik. Yogyakarta: Penerbit Andi.
2010. Pengantar Semantik Bahasa Indonesia. Yogyakarta: Pustaka Pelajar.

Wijana, I Dewa Putu dan Rohmadi, 2007. Sosiolinguistik Kajian Teori Dan Analisis. Yogyakarta: Pustaka Pelajar. 